\title{
Analisis Penerimaan Karyawan Pada PT. Srikandi Diamond Indah Motors Sampit Dengan Metode Analitycal Hierarchy Process (AHP) Dan Simple Additive Weighting (SAW)
}

\author{
Meidy Saputra ${ }^{[1]}$, Lukman Bachtiar ${ }^{[2]}$ \\ Program Studi Sistem Informasi, \\ Universitas Darwan $\mathrm{Ali}^{[1], \text { [2] }}$ \\ Sampit, Kalimantan Tengah, Indonesia \\ meidysaputra40@gmail.com ${ }^{[1]}$, lukman.bachtiar@gmail.com ${ }^{[2]}$
}

\begin{abstract}
PT. Srikandi Diamond Indah Motors is a company engaged in the automotive sector, having its address at Jalan Jendral Sudirman Km. 2.6 Sampit, Central Kalimantan. The problems that occur in PT. Srikandi Diamond Indah Motors is the selection of employees still using the handwriting system, many criteria and sub-criteria in employee selection and requires a lot of time in conducting assessments. From these problems the researcher proposes a decision support system website for employee recruitment at PT. Srikandi Diamond Indah Motors using two methods of Analytical Hierarchy Process (AHP) and Simple Additive Weighting (SAW). The result of this study is a website-based decision support system using the AHP and SAW methods, the percentage obtained from the comparison of the two methods is $50 \%$ with which of the 4 alternatives there are 2 alternatives in common, thus the decision support system built can assist in the selection employee acceptance.
\end{abstract}

Keywords- Decision Support System (DSS); Analytical Hierarchy Process (AHP); Simple Additive Weighting (SAW); employee recruitment, Website-Based

Abstrak - PT. Srikandi Diamond Indah Motors adalah salah satu perusahaan yang bergerak pada bidang otomotif yang beralamat di jalan Jendral Sudirman Km. 2,6 Sampit, Kalimantan Tengah. Permasalahan yang terjadi pada PT. Srikandi Diamond Indah Motors adalah pemilihan karyawan masih menggunakan sistem tulis tangan, banyaknya kriteria dan sub kriteria dalam pemilihan karyawan dan memerlukan banyak waktu dalam melakukan penilaian. Dari permasalahan tersebut peneliti mengusulkan sebuah website sistem pendukung keputusan untuk penerimaan karyawan pada PT. Srikandi Diamond Indah Motors dengan menggunakan dua metode Analitycal Hierarchy Process (AHP) dan Simple Additive Weighting (SAW). Hasil dari penelitian ini adalah sebuah sistem pendukung keputusan berbasis website dengan menggunakan metode AHP dan SAW, presentase yang diperoleh dari perbandingan kedua metode sebesar $50 \%$ dengan dimana dari 4 alternatif terdapat kesamaan hasil sebanyak 2 alternatif dengan demikian sistem pendukung keputusan yang dibangun dapat membantu dalam seleksi penerimaan karyawan.
Kata Kunci-Sistem Pendukung keputusan (SPK); Anailitycal Hierarchy Process (AHP); Simple Additive Weighting (SAW); penerimaan karyawan;berbasis website

\section{PENDAHULUAN}

Perkembangan teknologi di dalam kehidupan manusia di era global saat ini berkembang cukup pesat, manusia akan selalu berhubungan dengan teknologi. Perkembangan Teknologi Informasi (TI) telah memberikan manfaat yang begitu besar di segala bidang kehidupan. Teknologi bisa juga digunakan dalam sistem pengambilan keputusan Decision Support System (DSS) atau dikenal juga dengan Sistem Pendukung Keputusan (SPK). Sistem Pendukung Keputusan bisa diterapkan diberbagai aspek pengambilan keputusan seperti dalam seleksi perekrutan karyawan pada sebuah perusahaan, instansi dan dalam lembaga lainnya.

Sistem pendukung keputusan merupakan suatu sistem yang dirancang khususnya untuk proses pengambilan keputusan. Hampir semua perusahaan, instansi dan dalam lembaga lainnya mulai dari skala kecil maupun skala besar dalam melakukan kegiatan penerimaan karyawan mulai membuat keputusan dengan menggunakan metode sistem pendukung keputusan untuk menunjang kinerja perusahaannya. Dengan menggunakan sistem pendukung keputusan dalam perekrutan karyawan perusahaan akan lebih selektif lagi dalam memilih calon karyawan yang berkualitas guna menunjang kinerja dalam perusahaan tersebut.

Pemilihan pada karyawan di suatu perusahaan akan ada pertimbangan disaat pelamar memiliki pengalaman dan keahliannya masing - masing. Dari pihak perusahaan juga tidak ada menerapkan suatu sistem untuk menunjang sebuah keputusan dalam melakukan seleksi penerimaan karyawan, pemilihan calon karyawan masih menggunakan sistem tulis tangan, banyaknya kriteria dan sub kriteria dalam pemilihan karyawan dan memerlukan banyak waktu dalam melakukan penilaian.

Dari permasalahan yang telah dipaparkan maka penulis 
mengusulkan sebuah Sistem Pendukung Keputusan Penerimaan Karyawan mengunakan metode Analitycal Hierarchy Process (AHP) dan Simple Additive Weighting (SAW) berbasis website guna mempermudah dan mempercepat dalam proses seleksi penerimaan karyawan. Metode ini nantinya akan melakukan proses seleksi berdasarkan kriteria - kriteria yang sudah di tentukan oleh perusahaan dengan perhitungan yang membandingkan dari 2 metode mana yang lebih efektif untuk penilaian terhadap pelamar yang sesuai kriteria dari perusahaan tersebut.

Di bawah ini merupakan penelitian terdahulu yang memiliki kesamaan dalam judul untuk sebagai acuan peneliti dalam melakukan penelitian. Penelitian dilakukan oleh Bayu Rianto (2016). Yang menghasilkan sebuah program sistem pendukung keputusan berbasis dekstop untuk penerimaan karyawan pada Rumah Bersalin Nilam Sari Tembilan. [1]

Penelitian dilakukan oleh M Ilham A Siregar, Danyl Mallisza, Wahyuni Yahyan Dan Harry Setya Hadi (2019), dari penelitian tersebut menghasilkan analisa perhitungan penerimaan pegawai pada Universitas Ekasakti berbasis website dengan menggunakan metode AHP.[2]

Penelitian selanjutnya, dilakukan oleh Yulistia, Ricki Andira Lesmono Dan Rendi Harefa (2020). Dari penelitian ini menghasilkan perhitungan sistem pedukung keutusan penerimaan pegawai dengan menggunakan metode AHP yang bertujuan untuk membantu pihak Hotel RC menyeleksi penerimaan pegawai yang dilakukan. [3] Penelitian selanjutnya dilakukan oleh Alex Rikki, Murni Marbun, Jonson R.Siregar (2016), dari penelitian tersebut menghasilkan sebuah sistem pendukung keputusan berbasis dekstop yang bertujuan untuk membantu pihak PT. ISS Indonesia melakukan pemilihan ksryawan terbaik. [4]

Penelitian terakhir dilakukan oleh Rohmat Taufiq, Angga Aditya Permana, Tedi Cahyanto, Rizki Adha (2018). Dengan menerapkan sebuah metode sistem pendukung keputusan model SAW ke dalam aplikasi baru ini, dapat membandingkan penilaian yang akurat sehingga mendapatkan calon karyawan yang sesuai dengan perusahaan butuhkan. Penelitian tersebut menghasilkan sebuah sistem pendukung keputusan berbsis website. [5]

\section{LANDASAN TEORI}

\section{A. Rekrutmen atau Penerimaan}

Rekrutmen pada dasarnya merupakan usaha untuk mengisi jabatan atau pekerjaan yang kosong di lingkungan suatu organisasi atau perusahaan. Penarikan (rekrutmen) pegawai merupakan suatu proses atau tindakan yang dilakukan oleh organisasi untuk mendapatkan tambahan pegawai melalui beberapa tahapan. [6]

\section{B. Sistem Pendukung Keputusan}

Sistem Pendukung Keputusan (SPK) adalah sebuah sistem yang memberikan kemampuan pemecahan masalah maupun kemampuan pengkomunikasian untuk masalah dengan kondisi semi terstruktur dan tidak terstruktur. SPK bertujuan untuk menyediakan informasi, membimbing, memberikan prediksi serta mengarahkan kepada pengguna informasi agar dapat melakukan pengambilan keputusan dengan lebih baik [5].

\section{Analitycal Hierarchy Process (AHP)}

Analitycal Hierarchy Process (AHP) adalah metode memecahkan suatu permasalahan yang komplek tidak terstruktur kedalam susunan hirarki, dengan memberi nilai yang subjektif setiap variabel secara relatif. Proses pengambilan keputusan pada dasarnya adalah memilih suatu alternatif terbaik. [7].

\section{Simple Additive Weighting (SAW)}

Simple Additive Weighting (SAW) sering juga dikenal istilah metode penjumlahan terbobot. Konsep dasar metode SAW adalah mencari penjumlahan terbobot dari rating kinerja pada setiap alternatif semua atribut (Fishburn, 1967) dan (MacCrimmon, 1968).

Metode SAW membutuhkan proses normalisasi matriks keputusan (X) ke suatu skala yang dapat diperbandingkan dengan semua rating alternatif yang ada. Metode SAW sering juga dikenal istilah metode penjumlahan terbobot. Konsep dasar metode SAW adalah mencari penjumlahan terbobot dari rating kinerja pada setiap alternatif pada semua atribut. Metode SAW membutuhkan proses normalisasi matriks keputusan (X) ke suatu skala yang dapat dibandingkan dengan semua rating alternatif yang ada [8].

\section{METODOLOGI PENELITIAN}

Metodologi penelitian yang dilakukan yaitu mengumpulkan data dan informasi yang sesuai dengan permasalahan yang akan di bahas. Adapun metode penelitian yang digunakan dalam penelitian ini adalah sebagai berikut :

1. Wawancara

Melakukan wawancara kepihak HRD di PT. Srikandi Diamond Indah Motors untuk mendapatkan informasi data tentang tahapan dan proses perekrutan karyawan.

2. Observasi

Observasi dilakukan untuk melihat keadaan di PT. Srikandi Diamond Indah Motors secara langsung guna memastikan data dan informasi perekrutan yang ada disana yang sudah di dapatkan, hal ini juga bertujuan untuk mendapatkan data dan informasi yang valid dengan melakukan pengamatan langsung ke lapangan.

3. Studi Literatur

Studi Literatur yaitu mengumpulan dan mempelajari penelitian - penelitian yang terdahulu yang berupa jurnal, atau file lainnya. Dengan mengumpulkan dan mempelajari penelitian yang terdahulu kita bisa mengetahui bagaimana penggunaan metode AHP dan SAW dalam sistem pendukung keputusan

Pada Gambar 1, pertama dilakukan persiapan input data kriteria dan alternatif. Tahap input data kriteria dan alternatif hingga normalisasi matriks untuk kedua metode sama. Setelah melalui proses normalisasi, kemudian dilakukan perhitungan antara dua metode sistem pendukung keputusan yaitu AHP dan SAW. Nilai 
perhitungan dari metode AHP dan SAW dibandingkan sehingga menghasilkan keputusan akhir untuk tiap alternatif. Peringkat nilai tertinggi adalah alternatif yang lolos seleksi penerimaan.

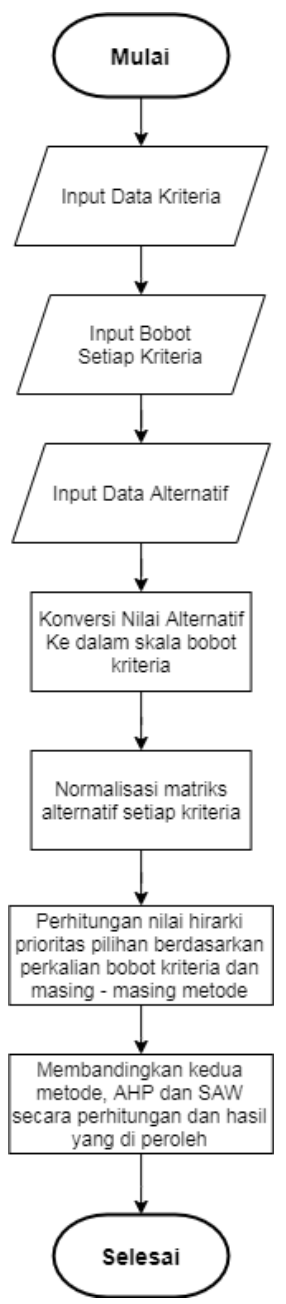

Gambar 1 Alur Penelitian

\section{HASIL DAN PEMBAHASAN}

Pada penelitian ini terdapat terdapat kasus dalam penyeleksian penerimaan karyawan di perusahaan PT. Srikandi Diamond Indah Motor. Sampel data calon pelamar dijadikan alternatif dalam melakukan proses seleksi penerimaan karyawan terdiri empat orang karyawan.

Tabel 1 Data Alternatif

\begin{tabular}{|c|c|c|}
\hline No & Nama & $\begin{array}{c}\text { Kode } \\
\text { Alternatif }\end{array}$ \\
\hline 1 & Joko & A01 \\
\hline 2 & Dendi & A02 \\
\hline 3 & Rizky & A03 \\
\hline 4 & Amel & A04 \\
\hline
\end{tabular}

Sumber : Penelitian (2021)
Terdapat lima kriteria yang akan digunakan sebagai acuan penilain penerimaan karyawan pada PT. Srikandi Diamond Indah Motors yaitu :

Tabel 2 Data Kriteria

\begin{tabular}{|c|c|}
\hline Kode & Nama Kriteria \\
\hline $\mathrm{C} 1$ & Usia \\
\hline $\mathrm{C} 2$ & Pendidikan \\
\hline $\mathrm{C} 3$ & Pengalaman \\
\hline $\mathrm{C} 4$ & Wawancara \\
\hline $\mathrm{C} 5$ & Tes Tertulis \\
\hline
\end{tabular}

Sumber : Penelitian (2021)

Dari lima kriteria diatas terdapat beberapa sub kriteria dari kriteria-kriteria yang telah ditentukan, dibawah ini merupakan tabel dari setiap sub-sub kriteria dari kriteria-kriteria yang ada.

Tabel 3 Sub Kriteria

\begin{tabular}{|c|c|c|}
\hline $\begin{array}{c}\text { Kode } \\
\text { Kriteria }\end{array}$ & Kriteria & Sub-Kriteria \\
\hline $\mathrm{C} 1$ & Usia & $\begin{array}{c}18,19,20,21,22,23,24 \\
25\end{array}$ \\
\hline $\mathrm{C} 2$ & Pendidikan & S1, D3, SMA \\
\hline $\mathrm{C} 3$ & Pengalaman & $\begin{array}{c}>1 \text { Tahun, }<1 \text { Tahun, } 0 \\
\text { Tahun }\end{array}$ \\
\hline $\mathrm{C} 4$ & Wawancara & $90,80,70,60,50$ \\
\hline C5 & Tes Tertulis & $100,90,80,70,60,50$ \\
\hline
\end{tabular}

Untuk melakukan penilaian dalam metode AHP terdapat standar kepentingan yang harus dilakukan sebelumnya. Dibawah ini adalah tabel dari standart kepentingan metode AHP.

Tabel 4 Standart Kepentingan Metode AHP

\begin{tabular}{|c|l|}
\hline 1 & Sama penting dengan \\
\hline 3 & Sedikit lebih penting dari \\
\hline 5 & Lebih penting dari \\
\hline 7 & Sangat penting dari \\
\hline 9 & Mutlak sangat penting dari \\
\hline $2,4,6,8$ & $\begin{array}{l}\text { Nilai tengah diantara dua pendapat yang } \\
\text { berdampingan }\end{array}$ \\
\hline
\end{tabular}

Sumber : Penelitian (2021)

\section{A. Perhitungan Manual Analytical Hierarchy Process (AHP)}

Perhitungan manual yang dilakukan menggunakan data alternatif berdasarkan usia, pendidikan, pengalaman, nilai wawancara serta nilai tes tertulis dari setiap karyawan yang ingin dinilai. Dibawah ini adalah tabel penilaian dari setiap kriteria yang akan dinilai.

Tabel 5 Data Alternatif

\begin{tabular}{|c|c|c|c|c|c|}
\hline $\begin{array}{c}\text { Kode } \\
\text { Alternatif }\end{array}$ & Usia & $\begin{array}{c}\text { Pendid } \\
\text { ikan }\end{array}$ & Pengalaman & Wawancara & $\begin{array}{c}\text { Tes } \\
\text { Tertulis }\end{array}$ \\
\hline A01 & 23 & SMA & $<1$ Tahun & 80 & 80 \\
\hline A02 & 22 & D3 & $<1$ Tahun & 90 & 80 \\
\hline A03 & 22 & D3 & 0 Tahun & 90 & 90 \\
\hline A04 & 21 & S1 & $<1$ Tahun & 80 & 70 \\
\hline
\end{tabular}

Sumber : Penelitian (2021) 
Selanjutnya dilakukan nilai perbandingan kepentingan antara kriteria satu dengan kriteria yang lainya dengan memperhatikan prioritas kepentingan pada tiap kriteria

Tabel 6 Matriks Perbandingan Kriteria

\begin{tabular}{|c|c|c|c|c|c|}
\hline & $\mathrm{C} 1$ & $\mathrm{C} 2$ & $\mathrm{C} 3$ & $\mathrm{C} 4$ & $\mathrm{C} 5$ \\
\hline $\mathrm{C} 1$ & 1 & 3 & 5 & 7 & 9 \\
\hline $\mathrm{C} 2$ & 0.333 & 1 & 3 & 5 & 7 \\
\hline $\mathrm{C} 3$ & 0.2 & 0.333 & 1 & 3 & 5 \\
\hline $\mathrm{C} 4$ & 0.14 & 0.2 & 0.333 & 1 & 3 \\
\hline C5 & 0.11 & 0.14 & 0.2 & 0.333 & 1 \\
\hline Total & 1.7873 & 4.6762 & 9.533 & 16.333 & 25 \\
\hline
\end{tabular}

Sumber : Penelitian (2021)

Dibawah ini penjelasan perhitungan dari Matrik Penilaian Perbandingan :

Baris C01 dengan Kolom C01 $=1 / 1=1$

Baris C02 dengan Kolom C01 $=1 / 3=0,333$

Baris C03 dengan Kolom C01 $=1 / 5=0,2$

Total $=1+0,333+0,2+0,14+0,11=1.7873$

Tahap selanjutnya adalah perhitungan dari Matrik Prioritas, dimana hasil dari Matriks Prioritas didapatkan dari nilai Kolom 1 dan Baris 1 dibagi dengan Total Jumlah Kolom C1.

Tabel 7 Matriks Prioritas Kriteria

\begin{tabular}{|c|c|c|c|c|c|c|c|c|}
\hline & C1 & C2 & C3 & C4 & C5 & C1 & Prioritas & CM \\
\hline C1 & 0.560 & 0.642 & 0.524 & 0.429 & 0.360 & 0.503 & 5.455 & 0.560 \\
\hline C2 & 0.187 & 0.214 & 0.315 & 0.306 & 0.280 & 0.260 & 5.432 & 0.187 \\
\hline C3 & 0.112 & 0.071 & 0.105 & 0.184 & 0.200 & 0.134 & 5.204 & 0.112 \\
\hline C4 & 0.080 & 0.043 & 0.035 & 0.061 & 0.120 & 0.068 & 5.030 & 0.080 \\
\hline C5 & 0.062 & 0.031 & 0.021 & 0.020 & 0.040 & 0.035 & 5.093 & 0.062 \\
\hline
\end{tabular}

Sumber : Penelitian (2021)

Tabel 8 Tabel Ordo Matriks

\begin{tabular}{|l|c|c|c|c|c|c|c|c|c|c|}
\hline $\begin{array}{c}\text { Ordo } \\
\text { Matriks }\end{array}$ & 1 & 2 & 3 & 4 & 5 & 6 & 7 & 8 & 9 & 10 \\
\hline $\begin{array}{l}\text { Ratio } \\
\text { Index }\end{array}$ & 0 & 0 & 0.58 & 0.9 & 1.12 & 1.24 & 1.32 & 1.41 & 1.46 & 1.49 \\
\hline
\end{tabular}

Adapun penjelasannya seperti dibawah ini :

Baris C01 dengan Kolom C01 $=1 / 1,7873=0,560$

Baris C02 dengan Kolom C01 = 0,333/1,7873 = 0,187

Baris C03 dengan Kolom C01 = 0,2/1,7873=0,112

Sedangkan prioritas didapatkan dari Jumlah Nilai Baris C1 dibagi dengan Jumlah Banyak Kriteria. Contonya 0,560 + $0,642+0,524+0,429+0,360=0,503$. Dan hasil dari $\mathbf{C M}$ adalah mengembalikan 2 (dua) nilai dari Matrik Perbandingan Kriteria dan Hasil Prioritas pada tabel 6 yang menghasilkan 5,445. Penjelasan hasil perhitungan dari CI sebagai berikut :

Tahap 1 Perhitungan CI

$=5,455+5,432+5,204+5,030+5,093=26,214$

Tahap 2 Perhitungan CI

$=($ Hasil Tahap 1 Perhitungan CI / Banyak Kriteria $)-$ Banyak

Kriteria $=(26,213 / 5)-5=0,243$
Tahap 3 Perhitungan CI

$=$ Banyak Kriteria -1

$=5-1=4$

Hasil Perhitungan CI

= Tahap 2 Perhitungan CI / Tahap 3 Perhitungan CI

$=0,243 / 4=0,061$

Nilai RI didapatkan dari tabel ordo matrik pada Tabel 7 Ordo Matrik, apabila jumlah kriterianya ada 5 maka Nilai RI adalah 1,12. Sedangkan nilai CR didapatkan dari CI / RI maka 0,061 / 1,12 menghasilkan nilai CR 0,05. Apabila nilai CR < 1 , maka nilai CR termasuk konsisten.

Dibawah ini contoh penilaian yang sudah diubah berdasarkan hasil perhitungan setiap sub kriteria:

Setelah dilakuan perhitungan Matrik Prioritas, tahap selanjutnya melakukan pembobotan terhadap Sub Kriteria dari masing-masing Kriteria. Yang pertama Sub Kriteria dari Usia untuk nilai dari Sub Kriteria dari Usia.

Tabel 9 Sub Kriteria Usia

\begin{tabular}{|c|c|c|c|c|c|c|c|c|}
\hline & U1 & U2 & U3 & U4 & U5 & U6 & U7 & U8 \\
\hline U1 & 1 & 1 & 1 & 1 & 1 & 1 & 1 & 1 \\
\hline U2 & 1 & 1 & 1 & 1 & 1 & 1 & 1 & 1 \\
\hline U3 & 1 & 1 & 1 & 1 & 1 & 1 & 1 & 1 \\
\hline U4 & 1 & 1 & 1 & 1 & 1 & 1 & 1 & 1 \\
\hline U5 & 1 & 1 & 1 & 1 & 1 & 1 & 1 & 1 \\
\hline U6 & 1 & 1 & 1 & 1 & 1 & 1 & 1 & 1 \\
\hline U7 & 1 & 1 & 1 & 1 & 1 & 1 & 1 & 1 \\
\hline U8 & 1 & 1 & 1 & 1 & 1 & 1 & 1 & 1 \\
\hline Total & 8 & 8 & 8 & 8 & 8 & 8 & 8 & 8 \\
\hline
\end{tabular}

Penilaian Matriks Perbandingan Sub Kriteria Usia dihitung dengan cara membandingkan sub kriteria Usia dengan sub kriteria Usia lainnya. Penjelasan perhitungan seperti dibawah ini :

Baris U1 dengan Kolom U1 = 1/1 = 1

Baris U2 dengan Kolom U1 $=1 / 1=1$

Baris U3 dengan Kolom U1 $=1 / 1=1$

Total $=1+1+1+1+1+1+1+1=8$

Sama dengan tahap sebelumnya sesudah melakukan Perbandingan Sub Kriteria Usia, selanjutnya dapat dilihat Matrik Prioritas Sub Kriteria Usia.

Tabel 10 Matrik Prioritas Sub Kriteria Usia

\begin{tabular}{|c|c|c|c|c|c|c|c|c|c|}
\hline U1 & U2 & U3 & U4 & U5 & U6 & U7 & U8 & Prioritas & Cm \\
\hline 0.125 & 0.125 & 0.125 & 0.125 & 0.125 & 0.125 & 0.125 & 0.125 & 0.125 & 8 \\
\hline 0.125 & 0.125 & 0.125 & 0.125 & 0.125 & 0.125 & 0.125 & 0.125 & 0.125 & 8 \\
\hline 0.125 & 0.125 & 0.125 & 0.125 & 0.125 & 0.125 & 0.125 & 0.125 & 0.125 & 8 \\
\hline 0.125 & 0.125 & 0.125 & 0.125 & 0.125 & 0.125 & 0.125 & 0.125 & 0.125 & 8 \\
\hline 0.125 & 0.125 & 0.125 & 0.125 & 0.125 & 0.125 & 0.125 & 0.125 & 0.125 & 8 \\
\hline 0.125 & 0.125 & 0.125 & 0.125 & 0.125 & 0.125 & 0.125 & 0.125 & 0.125 & 8 \\
\hline 0.125 & 0.125 & 0.125 & 0.125 & 0.125 & 0.125 & 0.125 & 0.125 & 0.125 & 8 \\
\hline 0.125 & 0.125 & 0.125 & 0.125 & 0.125 & 0.125 & 0.125 & 0.125 & 0.125 & 8 \\
\hline
\end{tabular}

Sumber : Penelitian (2021) 
Prioritas didapatkan dari Jumlah Nilai Baris U1 dibagi dengan Jumlah Banyak Sub Kriteria. Contonya 0,125 + $0,125+0,125+0,125+0,125+0,125+0,125+0,125=$ 0,125. Dan hasil dari CM adalah mengembalikan 2 (dua) nilai dari Matrik Perbandingan Sub Kriteria Usia dan Hasil Prioritas Sub Kriteria Usia menghasilkan 8. Penjelasan hasil perhitungan dari CI sebagai berikut :

Tahap 1 Perhitungan $\mathbf{C I}=8+8+8+8+8+8+8+8$

Tahap 2 Perhitungan $\mathbf{C I}=($ Hasil Tahap 1 Perhitungan CI $/$ Banyak Kriteria) - Banyak Kriteria $=(64 / 8)-8=0$

Tahap 3 Perhitungan CI $=$ Banyak Kriteria -1

$=8-1$

Hasil Perhitungan CI = Tahap 2 Perhitungan CI / Tsahap 3 Perhitungan CI

$=0 / 7=0$

Jumlah kriterianya ada 8 maka Nilai RI adalah 1,41. Sedangkan nilai CR didapatkan dari CI / RI maka 0 / 1,41 menghasilkan nilai CR 0 . Apabila nilai $\mathrm{CR}<1$, maka nilai CR termasuk konsisten.

Selanjutnya untuk melakukan perbandingan sub kriteria pendidikan, pengalaman, wawancara dan tes tertulis dilakukan dengan melakukan perhitungan yang sama pada sub kriteria usia.

Tabel 11 Matriks Perbandingan Sub Kriteria Pendidikan

\begin{tabular}{|c|c|c|c|}
\hline & PD1 & PD2 & PD3 \\
\hline PD1 & 1 & 3 & 5 \\
\hline PD2 & 0.333 & 1 & 3 \\
\hline PD3 & 0.2 & 0.333 & 1 \\
\hline Total & 1.533 & 4.333 & 9 \\
\hline
\end{tabular}

Sumber : Penelitian (2021)

Tabel 12 Matrik Prioritas Sub Kriteria Pendidikan

\begin{tabular}{|c|c|c|c|c|c|}
\hline & PD1 & PD2 & PD3 & Prioritas & CM \\
\hline PD1 & 0.652 & 0.692 & 0.5556 & 0.6333 & 3.072 \\
\hline PD2 & 0.217 & 0.231 & 0.3333 & 0.2605 & 3.033 \\
\hline PD3 & 0.13 & 0.077 & 0.1111 & 0.1062 & 3.011 \\
\hline \multirow{4}{*}{} & & CI & 0.019 \\
\cline { 4 - 5 } & & RI & 0.58 \\
\cline { 4 - 5 } & & CR & 0.033 \\
\cline { 4 - 5 }
\end{tabular}

Sumber : Penelitian (2021)

Tabel 13 Matriks Perbandingan Sub Kriteria Pengalaman

\begin{tabular}{|c|c|c|c|}
\hline & PL1 & PL2 & PL3 \\
\hline PL1 & 1 & 5 & 7 \\
\hline PL2 & 0.2 & 1 & 3 \\
\hline PL3 & 0.14286 & 0.333333 & 1 \\
\hline Total & 1.34286 & 6.333333 & 11 \\
\hline
\end{tabular}

Sumber : Penelitian (2021)

Tabel 14 Matrik Prioritas Sub Kriteria Pengalaman \begin{tabular}{l|l|l|l|l|} 
PL1 & PL2 & PL3 & Prioritas & CM \\
\hline
\end{tabular}

\begin{tabular}{|l|l|l|l|l|r|}
\hline PL1 & 0.74468 & 0.789474 & 0.6363636 & 0.724 & 3.141 \\
\hline PL2 & 0.14894 & 0.157895 & 0.2727273 & 0.193 & 3.043 \\
\hline PL3 & 0.10638 & 0.052632 & 0.0909091 & 0.083 & 3.014 \\
\hline \multirow{2}{*}{} & & CI & 0.03 \\
\cline { 4 - 5 } & & RI & 0.58 \\
\cline { 4 - 6 } & & CR & 0.057 \\
\hline
\end{tabular}

Sumber : Penelitian (2021)

Tabed 15 Matriks Perbandingan Sub Kriteria Wawancara

\begin{tabular}{|c|c|c|c|c|c|}
\hline & WW1 & WW2 & WW3 & WW4 & WW5 \\
\hline WW1 & 1 & 3 & 5 & 7 & 9 \\
\hline WW2 & 0.333 & 1 & 3 & 5 & 7 \\
\hline WW3 & 70.2 & 0.333 & 1 & 3 & 5 \\
\hline WW4 & 0.143 & 0.2 & 0.333 & 1 & 3 \\
\hline WW5 & 0.111 & 0.143 & 0.2 & 0.3333 & 1 \\
\hline Total & 1.787 & 4.676 & 9.533 & 16.333 & 25 \\
\hline
\end{tabular}

Sumber : Penelitian (2021)

Tabel 16 Matrik Prioritas Sub Kriteria Wawancara

\begin{tabular}{|c|c|c|c|c|c|c|c|}
\hline & WW1 & WW2 & WW3 & WW4 & WW5 & Prioritas & CM \\
\hline WW1 & 0.56 & 0.642 & 0.5245 & 0.4286 & 0.360 & 0.503 & 5.455 \\
\hline WW2 & 0.187 & 0.214 & 0.3147 & 0.3061 & 0.28 & 0.260 & 5.432 \\
\hline WW3 & 0.112 & 0.071 & 0.1049 & 0.1837 & 0.2 & 0.134 & 5.204 \\
\hline WW4 & 0.08 & 0.043 & 0.035 & 0.0612 & 0.12 & 0.068 & 5.030 \\
\hline WW5 & 0.062 & 0.031 & 0.021 & 0.0204 & 0.04 & 0.035 & 5.093 \\
\hline
\end{tabular}

Sumber : Penelitian (2021)

Tabel 17 Matriks Perbandingan Sub Kriteria Tes Tertulis

\begin{tabular}{|c|c|c|c|c|c|c|}
\hline & TS1 & TS2 & TS3 & TS4 & TS5 & TS6 \\
\hline TS1 & 1 & 2 & 3 & 5 & 7 & 9 \\
\hline TS2 & 0.5 & 1 & 2 & 3 & 5 & 7 \\
\hline TS3 & 0.333 & 0.5 & 1 & 2 & 3 & 5 \\
\hline TS4 & 0.2 & 0.333 & 0.5 & 1 & 2 & 3 \\
\hline TS5 & 0.143 & 0.2 & 0.333333 & 0.5 & 1 & 2 \\
\hline TS6 & 0.111 & 0.143 & 0.2 & 0.333 & 0.5 & 1 \\
\hline Total & 2.287 & 4.176 & 7.033333 & 11.83 & 18.5 & 27 \\
\hline
\end{tabular}

Sumber : Penelitian (2021)

Tabel 18 Matrik Prioritas Sub Kriteria Tes Tertulis

\begin{tabular}{|c|c|c|c|c|c|c|c|}
\hline TS1 & TS2 & TS3 & TS4 & TS5 & TS6 & $\begin{array}{c}\text { Priorita } \\
\text { s }\end{array}$ & $\mathrm{CM}$ \\
\hline 0.437 & 0.479 & 0.42654 & 0.423 & 0.378 & 0.333 & 0.413 & 6.112 \\
\hline 0.219 & 0.239 & 0.28436 & 0.254 & 0.27 & 0.259 & 0.254 & 6.098 \\
\hline 0.146 & 0.12 & 0.14218 & 0.169 & 0.162 & 0.185 & 0.154 & 6.059 \\
\hline 0.087 & 0.08 & 0.07109 & 0.085 & 0.108 & 0.111 & 0.090 & 6.041 \\
\hline 0.062 & 0.048 & 0.047393 & 0.042 & 0.054 & 0.074 & 0.055 & 6.013 \\
\hline 0.049 & 0.034 & 0.028436 & 0.028 & 0.027 & 0.037 & 0.034 & 6.027 \\
\hline & & & & & & $\mathrm{CI}$ & 0.012 \\
\hline & & & & & & RI & 1.24 \\
\hline & & & & & & $\mathrm{CR}$ & 0.009 \\
\hline
\end{tabular}

Sumber : Penelitian (2021)

Setelah semua data bobot prioritas setiap kriteria dan sub kriteria didapatkan selanjutnya adalah memasukan bobot alternatif sesuai dengan data pada alternatif. 
Tabel 19 Hasil Perhitungan Bobot Kriteria Masing-Masing Alternatif

\begin{tabular}{|c|c|c|c|c|c|c|}
\cline { 3 - 7 } \multicolumn{2}{c|}{} & C1 & C2 & C3 & C4 & C5 \\
\hline Kode & $\begin{array}{c}\text { Bobot } \\
\text { Kriteria }\end{array}$ & 0.503 & 0.260 & 0.134 & 0.068 & 0.035 \\
\hline A01 & Joko & 0.125 & 0.106 & 0.193 & 0.260 & 0.154 \\
\hline A02 & Dendi & 0.125 & 0.2605 & 0.193 & 0.503 & 0.154 \\
\hline A03 & Rizky & 0.125 & 0.2605 & 0.083 & 0.503 & 0.254 \\
\hline A04 & Amel & 0.125 & 0.2605 & 0.193 & 0.260 & 0.090 \\
\hline
\end{tabular}

Sumber : Penelitian (2021)

Dibawah ini adalah hasil dari metode AHP dan perengkingan yang dilakukan dengan melakukan pejumlahan antara baris bobot kriteria dan baris alternatif sehingga mendapatkan nilai total yang kemudian dilakukan perengkingan.

Tabel 20 Hasil Penjumlahan Dan Perangkingan Metode AHP

\begin{tabular}{|c|c|}
\hline Total & Ranking \\
\hline 0.1394 & 4 \\
\hline 0.1960 & 1 \\
\hline 0.1848 & 2 \\
\hline 0.1774 & 3 \\
\hline
\end{tabular}

Sumber : Penelitian (2021)

\section{B. Perhitungan Manual SAW}

Pada implementasi perhitungan metode SAW mengambil nilai bobot kriteria dari masing - masing alternatif pada perhitungan metode AHP yang kemudian dilakukan normalisasi dan pembobotan setelah itu dilakukan perengkingan.

Tabel 21 Hasil Perhitungan BobotKriteria Masing-Masing Alternatif

\begin{tabular}{|c|c|c|c|c|c|c|}
\cline { 3 - 7 } \multicolumn{2}{c|}{} & C1 & C2 & C3 & C4 & C5 \\
\hline Kode & $\begin{array}{c}\text { Bobot } \\
\text { Kriteria }\end{array}$ & 0.503 & 0.260 & 0.134 & 0.068 & 0.035 \\
\hline A01 & Joko & 0.125 & 0.106 & 0.193 & 0.260 & 0.154 \\
\hline A02 & Dendi & 0.125 & 0.260 & 0.193 & 0.503 & 0.154 \\
\hline A03 & Rizky & 0.125 & 0.260 & 0.083 & 0.503 & 0.254 \\
\hline A04 & Amel & 0.125 & 0.260 & 0.193 & 0.260 & 0.090 \\
\hline
\end{tabular}

Sumber : Penelitian (2021)

Hasil Perhitungan Bobot Kriteria Masing-Masing Alternatif didapatkan dari proses perhitungan AHP pada Tabel 19 Selanjutnya dilakukan normalisasi data dengan melakukan pembagian nilai MAX dari baris 1 dengan semua baris pada kolom.

Tabel 22 Hasil Normalisasi

\begin{tabular}{|c|c|c|c|c|c|c|}
\cline { 3 - 7 } \multicolumn{2}{c|}{} & C1 & C2 & C3 & C4 & C5 \\
\hline Kode & $\begin{array}{c}\text { Bobot } \\
\text { Kriteria }\end{array}$ & 0.503 & 0.260 & 0.134 & 0.068 & 0.035 \\
\hline
\end{tabular}

\begin{tabular}{|l|c|c|c|c|c|c|}
\hline A02 & Dendi & 1 & 1 & 1 & 1 & 0.606 \\
\hline A03 & Rizky & 1 & 1 & 0.431 & 1 & 1 \\
\hline A04 & Amel & 1 & 1 & 1 & 0.518 & 0.355 \\
\hline
\end{tabular}

Sumber : Penelitian (2021)

Melakukan proses perkalian antara tabel Nilai Alternatif dengan melakukan proses membagi nilai atas yaitu 0,106 pada kolom Pendidikan di tabel Nilai Alternatif, penjelasan seperti dibawah ini :

Baris 1 kolom $1=0,106$ / Nilai Maksimal dari baris 1 sampai dengan $4=0,408$

Baris 2 kolom $1=0,260$ / Nilai Maksimal dari baris 1 sampai dengan $4=1$

Baris 3 kolom $1=0,260$ / Nilai Maksimal dari baris 1 sampai dengan $4=1$

Baris 4 kolom $1=0,260$ / Nilai Maksimal dari baris 1 sampai dengan $4=1$

Begitu seterusnya dilakukan pada Kriteria Usia, Pengalaman, Wawancara dan Tes Tertulis.

Selanjutnya dilakukan pembobotan pada alternatif disetiap masing-masing kriteria, seperti Tabel 10 dibawah ini:

Tabel 23 Pembobotan

\begin{tabular}{|c|c|c|c|c|c|c|}
\cline { 3 - 7 } \multicolumn{2}{c|}{} & C1 & C2 & C3 & C4 & C5 \\
\hline kode & $\begin{array}{c}\text { Bobot } \\
\text { Kriteria }\end{array}$ & 0.503 & 0.260 & 0.134 & 0.068 & 0.035 \\
\hline A02 & Joko & 0.5028 & 0.1060 & 0.1344 & 0.0351 & 0.0211 \\
\hline A03 & Dendi & 0.5028 & 0.2602 & 0.1344 & 0.0678 & 0.0211 \\
\hline A04 & Amel & 0.5028 & 0.2602 & 0.0579 & 0.0678 & 0.0348 \\
\hline
\end{tabular}

Sumber : Penelitian (2021)

Penjelasan proses pembobotan pada kolom Kriteria Usia dengan melakukan proses perkalian seperti $1 \mathrm{X}$ dengan nilai bobot yaitu 0,503 dengan hasil pada kolom terbobot 0,503, selanjutnya penjelasan dibawah ini :

Baris 1 kolom $1=0,1250 \times 0,503=0,5028$

Baris 2 kolom $1=0,1250 \times 0,503=0,5028$

Baris 3 kolom $1=0,1250 \times 0,503=0,5028$

Baris 4 kolom $1=0,1250 \times 0,503=0,5028$

Selanjutnya dilakukan penjumlahan dan perankingan, seperti tabel dibawah ini :

Tabel 24 Hasil Penjumlahan Dan Perangkingan Metode SAW

\begin{tabular}{|c|c|}
\hline Total & Ranking \\
\hline 0.7994 & 4 \\
\hline 0.9863 & 1 \\
\hline 0.9236 & 3 \\
\hline 0.9449 & 2 \\
\hline
\end{tabular}

Hasil diatas didapatkan dengan cara melakukan menjumlahkan semua nilai pada setiap baris dan mendapatkan hasilnya, kemudian untuk mempermudah maka dilakukan perengkingan dengan rumus RANK untuk memperjelas siapa 
yang mendapatkan nilai tertinggi.

\section{Hasil Perhitungan Dan Perangkingan Pada Sistem}

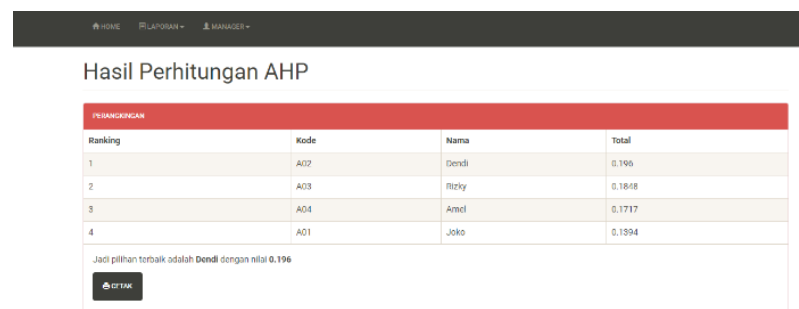

Gambar 2 Hasil Dari Perhitungan Metode AHP

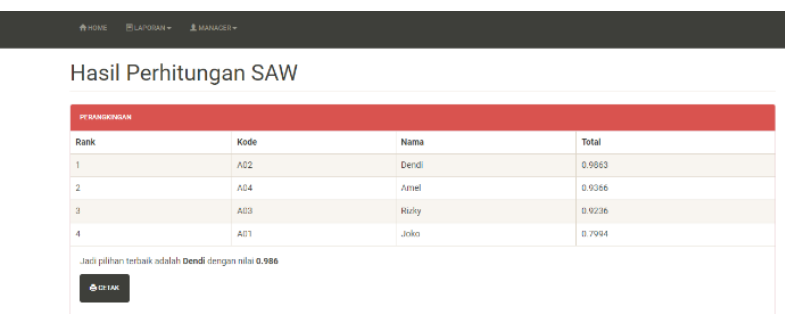

Gambar 3 Hasil Dari Perhitungan Metode SAW

Dari hasil perhitungan sistem didapatkan data yang sama antara perhitungan manual, hal ini bisa diartikan bahwa penerpan metode SAW dan AHP bisa di implementasikan dengan sistem.

Setelah dilakukan perhitungan data menggunakan metode AHP dan SAW, dapat disimpulkan bahwa hasil masing-masing metode menunjukan akurasi $100 \%$ karena perhitungan manual pada metode SAW dan AHP sama dengan hasil perhitungan pada sistem.

Untuk pengujian akurasi perbandingan kedua metode diperoleh dengan mencocokan hasil seleksi penerimaan karyawan antara metode AHP dan SAW. Hasil pengujian akurasi dapat ditentukan dengan menggunakan rumus

$$
\text { Akurasi }(\%)=\frac{\sum \text { data } \text { uji benar }}{\sum \text { data } \text { uji total }} \times 100 \%
$$

Tabel 25 Hasil Pengujian Akurasi

\begin{tabular}{|c|c|c|}
\hline $\begin{array}{c}\text { Hasil Perhitungan } \\
\text { SAW }\end{array}$ & $\begin{array}{c}\text { Hasil Perhtiungan } \\
\text { AHP }\end{array}$ & Akurasi \\
\hline A02 & A02 & 1 \\
\hline A04 & A04 & 1 \\
\hline A03 & A01 & 0 \\
\hline A01 & A03 & 0 \\
\hline
\end{tabular}

Berdasarkan hasil uji akurasi dengan melakukan perbadingan antara hasil seleksi metode AHP dan SAW, menunjukan bahwa hasil presentase yang diperoleh sebesar $50 \%$ dengan dimana dari 4 data alternatif terdapat kesamaan hasil sebanyak 2 data alternatif dengan demikian sistem pendukung keputusan yang dibangun dapat membantu seleksi penerimaan karyawan.

\section{PENUTUP}

Dengan melakukan analisis terhadap sistem yang sedang berjalan pada proses seleksi penerimaan karyawan menggunakan metode Simple Additive Weighting (SAW) dan Analitycal Hierarchy Process (AHP) kemudian dilakukan implementasi pada sistem dengan menerapkan rumus-rumus perhitungan metode Simple Additive Weighting (SAW) dan Analitycal Hierarchy Process (AHP) dapat membangun dan merancang sebuah sistem pendukung keputusan seleksi penerimaan karyawan.

Menerapkan metode Simple Additive Weighting (SAW) dan Analitycal Hierarchy Process (AHP) dengan melakukan analisis terhadap kedua metode dapat diterapkan dalam melakukan seleksi penerimaan karyawan pada PT. Srikandi Diamond Indah Motors.

Berdasarkan hasil uji akurasi dengan melakukan perbandingan antara hasil seleksi metode AHP dan SAW, menunjukan bahwa hasil presentase yang diperoleh sebesar $50 \%$ dengan dimana dari 4 alternatif terdapat kesamaan hasil sebanyak 2 alternatif dengan demikian sistem pendukung keputusan yang dibangun dapat membantu seleksi penerimaan karyawan pada PT. Srikandi Diamond Indah Motors.

\section{DAFTAR PUSTAKA}

[1] B. Rianto, "Sistem Pendukung Keputusan Penerimaan Karyawan Menggunakan Metode Analytical Hierarchy Process ( AHP ) Studi Kasus : RB . Nilam Sari Tembilahan," vol. 2, no. 2, pp. 29-38, 2016.

[2] J. Khatib and S. Dalam, "Indonesian Journal of Computer Science," vol. 8, no. 1, pp. 45-54, 2019.

[3] Yulistia, R. A. Lesmono, and R. Harefa, "Sistem Pendukung Keputusan Penerimaan Pegawai Menggunakan Metode AHP ( Analytical Hierarchy Process ) Hotel RC Di Palembang," Jtsi, vol. 1, no. 1, pp. 65-72, 2020.

[4] A. Rikki, M. Marbun, and J. R. Siregar, "Sistem Pendukung Keputusan Penerimaan Karyawan Dengan Metode SAW Pada PT. Karya Sahata Medan," J. Informatics Pelita Nusant., vol. 1, no. 1, pp. 38-46, 2016.

[5] R. Taufiq, A. A. Permana, T. Cahyanto, and R. Adha, "Sistem Pendukung Keputusan Penerimaan Karyawan Menggunakan Simple Additive Weighting Studi Kasus PT. Trafoindo Prima Perkasa," vol. 4, no. 4, pp. 186-194, 2018.

[6] B. Pottale, "Pengaruh Proses Rekrutmen Dan Seleksi Terhadap Kinerja Karyawan Pada Pt Bank Sulutgo," J. Berk. Ilm. Efisiensi, vol. 16, no. 4, pp. 453-464, 2016.

[7] Jadiaman Parhusip, "Penerapan Metode Analytical Hierarchy Process (AHP) Pada Desain Sistem Pendukung Keputusan Pemilihan Calon Penerima Bantuan Pangan Non Tunai (BPNT) Di Kota Palangka Raya," J. Teknol. Inf. J. Keilmuan dan Apl. Bid. Tek. Inform., vol. 13, no. 2, pp. 18-29, 2019, doi: $10.47111 /$ jti.v13i2.251. 
[8] M. S. . Utomo, "Penerapan Metode Saw ( Simple Additive Weight ) Pada Sistem Pendukung Keputusan Untuk Pemberian Beasiswa Pada Sma Negeri 1 Cepu Jawa Tengah," Fak. Ilmu Komput. Univ. Dian Nuswantoro, Semarang, pp. 1-12, 2015, [Online]. Available:

http://eprints.dinus.ac.id/15172/1/jurnal_14778.pdf. 